University of Nebraska - Lincoln

DigitalCommons@University of Nebraska - Lincoln

Papers in Biotechnology

Chemical and Biomolecular Engineering

Research and Publications

January 1999

\title{
A Red-Dot-Blot Protein Assay Technique in the Low Nanogram Range
}

Tiilin Marcol

Ben- Abraham Technologies Inc. 4600 Highlands Parkway, Suites A\& B, Smyrna, Georgia. 30082

Anuradha Subramanian

Department of chemical Engineering,University of Nebraska Lincoln., asubramanian2@unl.edu

Follow this and additional works at: https://digitalcommons.unl.edu/chemeng_biotechnology

Part of the Biochemical and Biomolecular Engineering Commons

Marcol, Tiilin and Subramanian, Anuradha, "A Red-Dot-Blot Protein Assay Technique in the Low Nanogram Range" (1999). Papers in Biotechnology. 40.

https://digitalcommons.unl.edu/chemeng_biotechnology/40

This Article is brought to you for free and open access by the Chemical and Biomolecular Engineering Research and Publications at DigitalCommons@University of Nebraska - Lincoln. It has been accepted for inclusion in Papers in Biotechnology by an authorized administrator of DigitalCommons@University of Nebraska - Lincoln. 
adford (1-3), bicinchoninic acid $(\mathrm{BCA})^{2}(4)$, wuwry (5) assays are the most widely used methods for the estimation of total protein concentration in solution. Although the original protocols were performed using reaction mixtures in the milliliter range, all of these colorimetric procedures, more recently, have been conveniently modified for the microtiter plates $(6-8)$, automating spectrophotometric readings. However, these assays are hampered by many interfe ing agents, such as detergents, reducing agents, and chelating agents present in the samples $(9-11)$. For instance, basic buffer conditions and detergents, such as sodium dodecyl sulfate and Triton X-100 above $0.1 \%$, are not recommended in the Bio-Rad protein assay which is based on the method of Bradford (12). It has been suggested that strong acids, bases, or buffers should be neutralized or adjusted to the optimal $\mathrm{pH}$ of the assay systems used (13). Furthermore, these techniques can measure proteins only in the microgram range.

Solid-phase assays which use nitrocellulose (NC) as the protein immobilization matrix, combined with dyestaining procedures, have been successfully used for the quantification of proteins in the nanogram range (14-17). Proteins stained on NC using a range of organic dyes, such as amido black, Ponceau S, Coomassie blue, and aurodye, can also be quantified by eluting dye-protein complexes into solution and determining the absorbance of the resulting solution spectrophotometrically (18-21). However, all of these techniques involve multiple steps of membrane preparation, fixation, destaining, and membrane-baking treatments, taking an average of $45 \mathrm{~min}$ to $2 \mathrm{~h}$ of assay time. Some procedures may even involve overnight incubations (22) and 20 to $400 \mu 1$ of protein solutions for testing (15, 17). Most often, $t$ ansferring of the stained protein spots into diffe ent matrixes, such as 96-well plates (21), for furtherrtreatments before densitometric measurements is required. In addition, detergent interfer- 
ence and protein-to-protein and $\mathrm{pH}$ variations seem to be problems in some solid-phase assays (15).

The present report describes a simple, rapid, reliable, sensitive, and highly reproducible solid-phase protein assay which can detect as low as $4 \mathrm{ng}$ of protein, offering a potential alternative to the most commonly used techniques in research laboratories. The

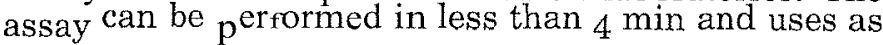
little as $1.0 \mathrm{pl}$ of sample, providing multiple format capabilities. The assay steps involve: (1) the immobilization of the proteins onto Ponceau S-coated nitrocellulose membrane, (2) cross-linking via glutaraldehyde, (3) rinsing in $\mathrm{NaOH}$; (4) restaining with Ponceau $\mathrm{S}$, and (5) destaining with acid water at $\mathrm{pH} 3$. The membranes containing stained protein spots can then be coated permanently with mineral oil and scanned on reflectance mode. Coated membranes can be stored for long periods of time with no loss of color intensity. Utilization of the technique was exemplified for six different proteins ovalbumin (OVA), human serum albumin (hSA), a rabbit polyclonal antibody to human albumin (rIgG), lysozyme (LYS), bovine insulin (bINS), and soybean trypsin inhibitor (TRI)) and for three buffer systems in the $\mathrm{pH}$ range of 4-9.5. Bovine serum albumin (BSA) was used as the protein reference in the assay. Detergent interference was investigated for SDS, Triton X-100, and digitonin. Interference of some other reagents commonly used in protein purification processes was also tested by utilizing $\mathrm{BSA}$ as the test protein. Data from the present assay were compared with those obtained from the Bradford assay. The assay shows tolerance to extreme acidic and basic buffer conditions and no significant protein-to-protein variations were observed. The nonionic detergent digitonin and the anionic SDS, up to $1 \%(\mathrm{w} / \mathrm{v})$, do not interfere with this assay. Although Triton X-100 at concentrations higher than $0.25 \%(\mathrm{w} / \mathrm{v})$ interfere with this technique, Triton $\mathrm{X}-100$ at $0.25 \%$ and lower concentrations is compatible with the assay.

\section{MATERIALS AND METHODS}

\section{Materials}

Nitrocellulose membrane (pore size: $0.45 \mathrm{pm}$ ) was obtained from Millipore Corp. (Bedford, MA). Lyophilized BSA (fraction V, globulin free), OVA (grade VI), hSA, polyclonal rabbit anti-human albumin (rIgG), LYS from chicken egg white, insulin from bovine pancreas (bINS), and soybean TRI were obtained from Sigma (St. Louis, MO). Triton X-100, digitonin, Ponceau $S$, and all the buffer reagents were also purchased from Sigma. SDS was obtained from Bio-Rad Laboratories (Richmond, CA). Mineral oil (Johnson \& Johnson) was obtained from a local drug store. All the other chemicals and solvents were analytical grade and were purchased from Sigma.

\section{Methods}

Protesn solutions and interfering substances. Stock solutions of OVA, LYS, rIgG, TRI, and hSA were pre-

pared gravimetrically in $10 \mathrm{mM}$ sodium phosphate buffer contanning $150 \mathrm{mM} \mathrm{NaCl}$ (PBS) at $\mathrm{pH} 7.2 . \mathrm{B}_{\mathrm{O}^{-}}$

vine insulin was not soluble at neutral $\mathrm{pH}$ and was solubilized with $0.1 \mathrm{~N}$ HCl. BSA dilutions with or without various detergents (Triton X-100, SDS, digitonin), in various buffers at different $\mathrm{pH}(0.1 \mathrm{M}$ acetate buffer

at $\mathrm{pH}$ 3.8, PBS at $\mathrm{pH} 5.5$, Tris-buffered saline (TBS) at $\mathrm{pH} 7.2$, and $0.1 \mathrm{M}$ carbonate buffer at $\mathrm{pH}^{9.5}$ ), and in various concentrations of chemical reagents listed in Table 1, were tested in the assay. Each protein stock (2 $\mathrm{mg} / \mathrm{ml}$ ) was twofold serially diluted (8-10 times) to facilitate comparison of protein concentrations. BSA prepared in PBS at pH 7.2 was used as the reference. Interference test was performed with only two BSA concentrations ( $8 \mu \mathrm{g} / \mathrm{ml}$ and $1 \mathrm{mg} / \mathrm{ml}$ ), as triplicates, for practical purposes. Minimal test concentrations were

chosen based on the data available in the Bio-Rad's Technical Bulletin (12) and increased gradually until a notable decrease in color intensity and densitometric signal were detected.

Membrane preparation. Ponceau S solution $(0.1$ $\mathrm{w} / \mathrm{v})$ was prepared in $15 \%$ phosphoric acid and $10 \%$ methanol (MeOH) in water. Sheets of NC membrane were dipped into dye solution until coated uniformly $(5-10 \mathrm{~s})$. Extra dye was blotted between two sheets of filter paper. Ponceau S-coated membranes were either air-dried at room temperature or blow-dried using a hair dryer. Stained membranes were stored covered between sheets of aluminum foil and used over a 6-month $\mathrm{p}^{\text {eriod when needed. }}$

Standard assay. Protein concentrations in the range of 0.004 to $2 \mathrm{mg} / \mathrm{ml}$ were applied to pre-Ponceau $\mathrm{S}$-stained $\mathrm{NC}$ membrane as $1-\mu \mathrm{l}$ spots. Spots were either air-dried at room temperature or blow-dried with a hair dryer. Dot-blotted membranes were fixed, stained, and destained in glass staining dishes as follows. Fifty-milliliter baths of each reagent and larger volumes of acid water at $\mathrm{pH} 3(50 \mu \mathrm{HCl} / 100 \mathrm{ml}$ $\mathrm{DiH}_{2} \mathrm{O}$ ) were prepared as duplicates: (i) immersion in first $1 \%$ glutaraldehyde bath in water for $30 \mathrm{~s}$, followed by a brief rinse in the second bath; while the Ponceau $\mathrm{S}$ in the memb ane background washes out, protein spots appear as red dots; (ii) immersion in $1 \mathrm{~N} \mathrm{NaOH}$ solution for $30 \mathrm{~s}$ is followed by a brief rinse in the second bath to remove residual glutaraldehyde; red protein spots first turn purple and then bleach out; (iii) rinsing in acid water for $30 \mathrm{~s}$ to neutralize $\mathrm{NaOH}$ and to preequilibrate the membrane for dye staining; (iv) staining in Ponceau $\mathrm{S}$ for $60 \mathrm{~s}$ (30 s in each bath); (v) destaining in large volumes of acid water until the protein spots appear as red dots on white background (approximately $30 \mathrm{~s}$ ); (vi) development is completed by 
a brief rinse in $10 \%$ methanol for a clear finish. Membrane was agitated during each step to achieve uniform staining and destaining. Once stained, color was permanent and excessive destaining in any of the reagents did not cause color fading or bleaching. Although the first baths of each reagent needed to be replaced after being used for five $5 \times 10-\mathrm{cm}$ membranes, second baths could be used five times as more and were stable for 6 weeks, when kept covered tightly.

Comparison with commercial protein staining reagents. Commercially available $0.1 \%$ Ponceau S solution in 5\% acetic acid (Sigma), which is widely used for reversible staining of proteins in Western blots, was used for staining of protein spots on NC. Proteins were applied as 1-p 1 spots on NC, stained 3-5 min with the dye solution, and rinsed with water to wash off the background. Excessive rinsing was avoided to preserve signals and the dried membranes were lubricated to preserve colored protein spots. Finished membranes were compared with the ones prepared using our standard procedure.

A microtiter plate version of the Bradford assay was also performed for the same test proteins (BSA, rIgG, LYS, OVA, hSA, bINS, TRI) using the Bio-Rad's protein dye reagent. In a 96 -well microtiter plate, $200 \mathrm{pl}$ of the diluted dye reagent and $10 \mathrm{pl}$ of varying protein dilutions in the range of 7.8 to $500 \mu \mathrm{g} / \mathrm{ml}$ were added according to the supplier's instructions (12). Absorbance of dye-protein complex was measured at $595 \mathrm{~nm}$ on a plate reader and plotted as a function of protein concentration. Percentage accuracy of the assay was estimated with respect to BSA from the ratios of the slopes in the linear range.

Membrane coating and densitometry. After the protein spots were developed, nitrocellulose membranes were coated lightly with mineral oil, as described below, for densitometric scanning and permanent storage. Membranes were dried at room temperature on a piece of filter paper and lubricated uniformly with baby oil using a cotton ball to achieve translucency of the background and brightness of the colored spots (stained protein spots are not transparent). Excess oil was wiped off with a clean cotton ball. Stained (bright red) protein spots on oil-coated membranes were scanned at reflectance mode on a Shimadzu DR-13 dual wavelength flying-spot scanner (CS-9000) at $560 \mathrm{~nm}$ and zigzag mode. Graphs of total area verses protein concentration (or total protein on the membrane) were prepared.

\section{RESULTS}

\section{Sensitivity and Reproducibility}

An example of staining patterns and the color intensity of BSA on $\mathrm{NC}$ in 0.004 to $2 \mathrm{mglml}$ ( $4 \mathrm{ng}$ to 2

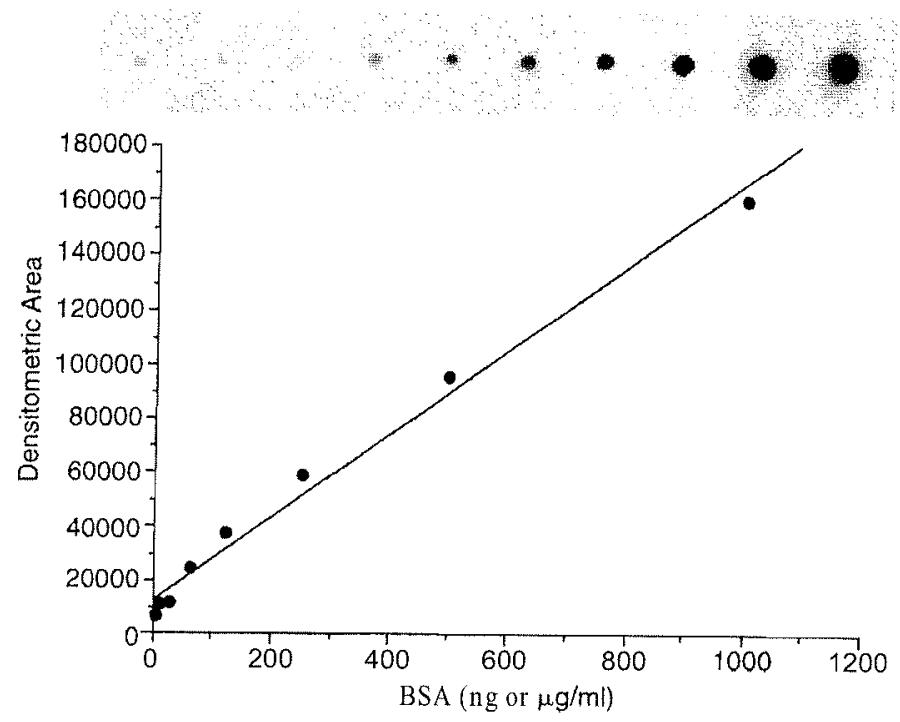

FIG. 1. Typical standard curve and staining pattern for BSA spots on $\mathrm{NC}$ membrane. BSA dilutions in $4 \mu \mathrm{g} / \mathrm{ml}$ to $2 \mathrm{mg} / \mathrm{ml}$ range were applied onto a pre-Ponceau S-stained membrane strip as 1-p1 spots. Membrane was treated with glutaraldehyde, $\mathrm{NaOH}$, and acid water and stained with $0.1 \%$ Ponceau $\mathrm{S}$ in $15 \%$ phosphoric and $10 \% \mathrm{MeOH}$ as described under Materials and Methods. Mineral oil lubricated membrane was scanned on a densitometer at $560 \mathrm{~nm}\left(y=9.6 e^{+3}\right.$ $+154.2 x, \mathrm{R}^{2}=0.988$ ).

$\mu \mathrm{g}$ on the membrane) concentration range is shown in Fig. 1. A good linearity was obtained for $1 \mathrm{p} 1$ spots of BSA in the range of 0.004 to $1 \mathrm{mglml}$ using Ponceau S. Reproducibility and the precision of the assay were examined by scanning BSA spots in 12 separate tests, performed on different membranes at different times within a 6-month period. The assay measured protein concentrations with a coefficient of variance (CV) that was typically less than 5\% (Fig. 2). Although the stained protein spots appeared slightly faded within a 4-week period, the color could be restored with no loss in intensity by relubrication with mineral oil. Developed membranes can be stored for over 6 months.

Prestaining of the membrane with Ponceau $\mathrm{S}$ before the sample application was found to be very effective in obtaining tighter, well-defined protein spots in comparison to the ones on untreated membranes. A visual and densitometric inspection of the stained protein spots developed on either prestained or untreated membranes indicated that prestaining contributes a $25 \%$ increase to assay sensitivity (not shown). In addition, prestaining also helps visual inspection of accurate sample pipetting during the assay.

Membranes developed using the commercial $0.1 \%$ Ponceau $\mathrm{S}$ in $5 \%$ acetic acid in a procedure similar to the one recommended for reversible staining of Western blots faded almost entirely within $72 \mathrm{~h}$ in spite of repeated oil lubrication (data not shown). 


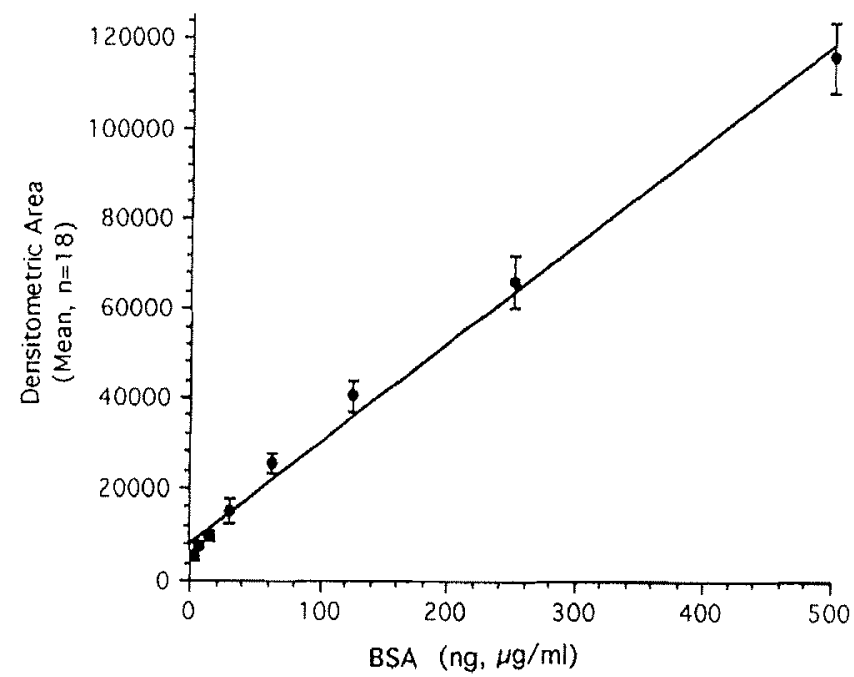

FIG. 2. Reproducibility of dot-blot protein assay using aged membranes which were prespotted with BSA. Multiple NC sheets were prestained with Ponceau S. $1-\mathrm{g} 1$ spots of varying BSA dilutions were applied onto six of these membranes as triplicates and stored in dark. One of the membranes was developed on day 1 and one membrane every 4 weeks within a 6 -month period (totaling to 18 replicates for each dilution). Protein spots were developed as described in the legend to Fig. $I$ and under Materials and Methods. Lubricated membranes were scanned at $560 \mathrm{~nm}$ and the mean of densitometric areas were plotted against total protein on membrane surface $(y=$ $\left.8.2 e^{+3}+221 x, R^{2}=0.994\right)$

\section{Effects of $p H$}

An example of staining densities of BSA dilutions prepared in four different buffer systems in the $\mathrm{pH}$ range 3.8 to 9.5 is shown in Fig. 3A. Reproducibility of staining patterns and color intensities were examined in two experiments performed at 2 weeks apart on prestained membranes. Each time, protein dilutions were applied on NC as quadruplicate spots. No notable differences in staining intensities or staining patterns were observed within the 3.8 to $9.5 \mathrm{pH}$ range. Calculated mean averages of densitometric signals (for 8 replicates/spot) in the $4 \mu \mathrm{g} / \mathrm{ml}$ to $2 \mathrm{mg} / \mathrm{ml}$ ( $4 \mathrm{ng}$ to $2 \mu \mathrm{g}$ on the membrane) range are shown in Fig. 3B. A good linearity between the densitometric area and the amount of protein was observed in the range from $4 \mathrm{ng}$ to $1 \mu \mathrm{g}$ (Fig. 3B, inset). The ratio of the slopes for each $\mathrm{pH}$ condition relative to the $\mathrm{pH} 7$ standard was within the 0.92 to 1.05 range. This indicates that total protein concentration for a wide range of $\mathrm{pH}$ conditions can be determined with a minimum of $92 \%$ accuracy within this assay's linear range.

\section{Effects of Detergents}

Possible assay interference from detergent was examined with BSA (in the range of $4 \mathrm{ng}$ to $2 \mu \mathrm{g}$ ) which was prepared in three different detergents in water at concentrations ranging from 0.1 to $1 \%$. Triton X-100, SDS, and digitonin were soluble in water, except that the digitonin stock solution had to be prepared by heating at $90^{\circ} \mathrm{C}$. BSA dilutions in TBS in the same concentration range were used for comparison. The assay was not significantly affected by any of the detergents at 0.1 and $0.25 \%$ concentrations. Figure 4

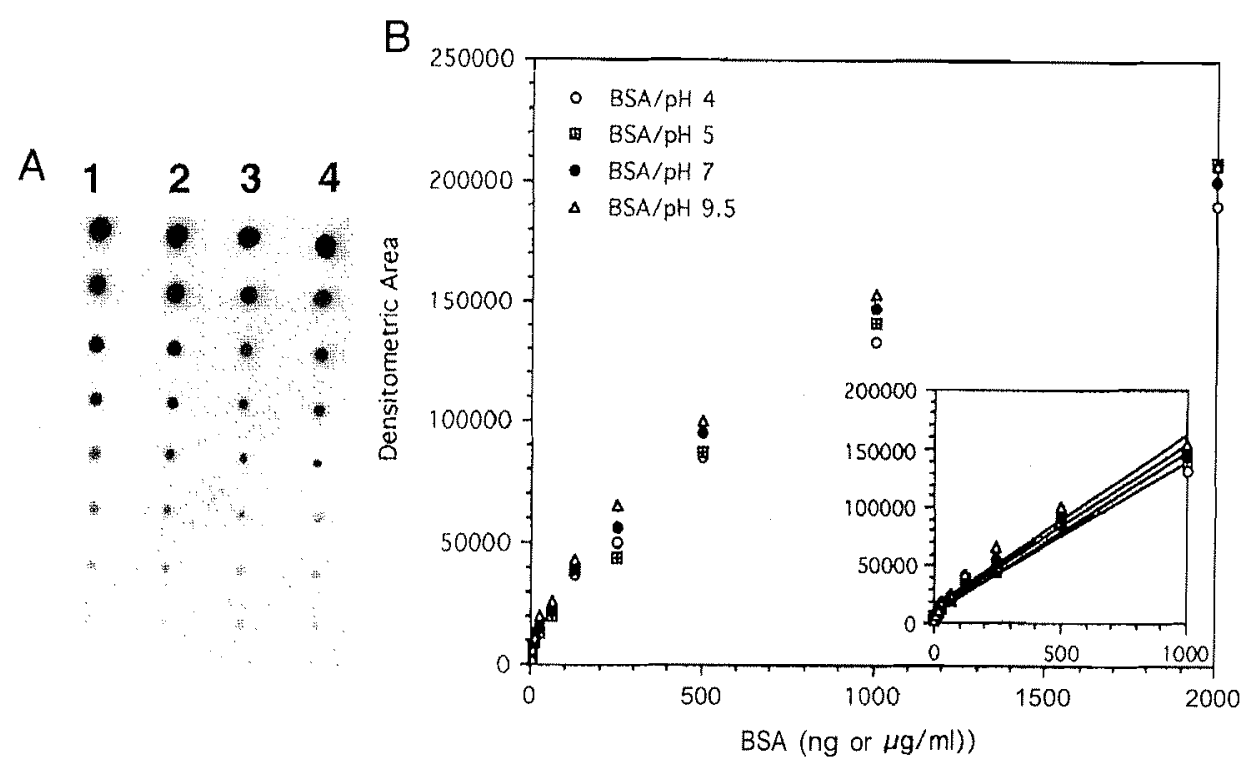

FIG. 3. Effects of $\mathrm{pH}$ on staining patterns of BSA spots on $\mathrm{NC}$ in the $4 \mu \mathrm{g} / \mathrm{ml}$ to $2 \mathrm{mg} / \mathrm{ml}$ concentration range. BSA dilutions were prepared either in acetate buffer ( $\mathrm{pH}$ 3.8), PBS (pH 5.5), TBS ( $\mathrm{pH} 7.2$ ), or carbonate buffer (pH 9.5). 1-g1 spots were applied onto prestained NC membranes. Protein spots were developed as described under materials and Methods. (A) Typical staining patterns of BSA in pH 3.8 (lane 1); pH 5.5 (lane 2); pH 7.2) (lane 3) and; pH 9.5 (lane 4). Each lane contains 2000 ng (top) to 4 ng (bottom) BSA on the membrane. (B) Densitometric signals $(560 \mathrm{~nm})$ of BSA in high acidic to high basic buffer systems. Linear region of the plot is shown in the inset. 


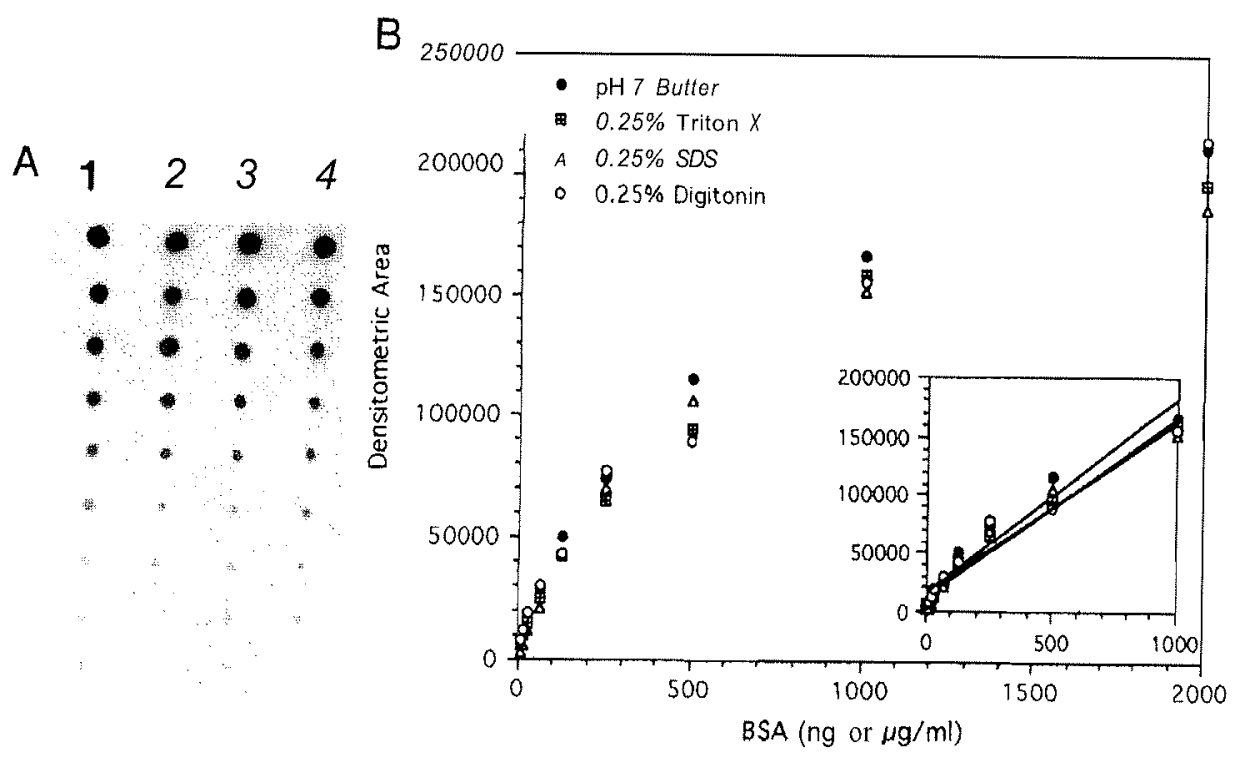

FIG. 4. Effects of detergent presence on the standard assay. BSA in the $4 \mu \mathrm{g} / \mathrm{ml}$ to $2 \mathrm{mg} / \mathrm{ml}$ range was prepared in $0.25 \%(\mathrm{w} / \mathrm{v})$ of each detergent: (A) Staining patterns of BSA in $0.25 \%$ digitonin (lane 1), SDS (lane 2), and Triton X-100 (lane 3). BSA in pH 7 TBS is shown in lane 4. (B)Stained protein spots were scanned with a densitometer at $560 \mathrm{~nm}$ on reflectance mode. Total areas obtained at zigzag mode were plotted against total protein on the membrane. Linear region of the plot is shown in the inset.

exemplifies the staining patterns (Fig. 4A) and the densitometric signals (Fig. 4B) of BSA prepared in $0.25 \%$ digitonin (lane 1), SDS (lane 2), and Triton X-100 (lane 3). In Fig. 4B, each data point represents a mean average of eight $1-\mathrm{p} 1$ spots applied as sets of quadruplicates on two different membranes in the 4 $\mu \mathrm{g} / \mathrm{ml}$ to $2 \mathrm{mg} / \mathrm{ml}$ concentration range. Mean average of combincd signals from two different membranes suggested an acceptable linearity, with coefficient of determination $-\left(R^{2}\right)$ ranging from 0.96 to 0.98 , in the 4 $\mu \mathrm{g} / \mathrm{ml}$ to $1 \mathrm{mglml}$ range (Fig. $4 \mathrm{~B}$, inset). The ratios of "slope of BSA curve in test detergent/slope of BSA curve in pH 7 buffer" were about 0.9 in the linear regime. This suggests that the total protein concentration of samples containing $0.25 \%$ of Triton X-100, SDS, or digitonin can be estimated within a $90 \%$ accuracy range when standard prepared in $\mathrm{pH} 7$ buffer is used as the assay reference. Using the target protein prepared in the proper detergent as the reference is recommended when higher accuracy is required.

Although 0.5 and $1 \%$ concentrations of SDS and digitonin did not interfere with the assay, Triton X-100 at concentrations higher than $0.25 \%$ interfered with the assay. As shown in Fig. 5, no significant spot spreading was observed for SDS and digitonin at $1 \%$ concentrations (lanes 1 and 2) but BSA at concentrations 0.5 mglml or lower could not be detected in $1 \%$ Triton $\mathrm{X}-100$ (lane 3). BSA prepared in TBS is shown in lane 4 as the protein reference in the assay. The same detergents were also tested in Bio-Rad's dye binding assay and allowable concentration limits were determined as shown in Table 1 . SDS, Triton-X, and digito- nin higher than $0.1 \%$ interfered with the Bio-Rad's protein detection system.

\section{Interfering Substances}

A list of contaminating chemicals tested for interference with BSA in the assay is shown in Table 1. Although they might produce interference in combination with other reagents and proteins, the listed reagents show very little or no interference at the concentrations indicated in Table 1. Higher concentrations for urea, 2-mercaptoethanol, polyethylene glycol

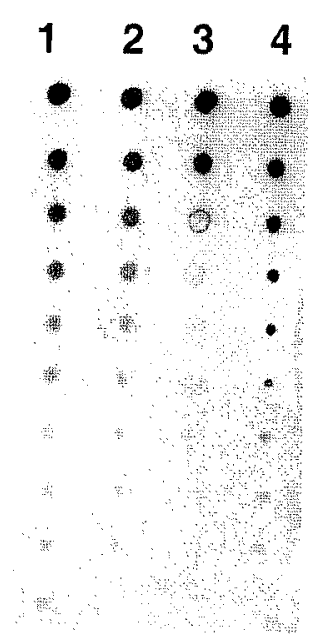

FIG. 5. Triton X-100 interference at $1 \%(\mathrm{w} / \mathrm{v})$ concentration. Lane $1,1 \%$ digitonin; lane 2, $1 \%$ SDS; lane 3, $1 \%$ Triton X-100. BSA prepared in TBS was used for comparison in lane 4. 
TABLE 1

List of Some Reagents Which Are Compatible with the Dot-Blot and Bio-Rad Assays

\begin{tabular}{lcc}
\hline Interfering substance & Bio-Rad assay" & Dot-blot assay \\
\hline Acctate buffer & $0.6 \mathrm{M}$ & $1.0 \mathrm{M}$ \\
Acetone & & \\
Acid pH & $\mathrm{NC}$ & $\mathrm{C}$ \\
Basic pH & $1.0 \mathrm{M}$ & $1.0 \mathrm{M}$ \\
Ammonium sulfate & $0.05 \mathrm{M}$ & $1.0 \mathrm{M}$ \\
Citrate buffer & $0.1 \%$ & $1.0 \%$ \\
Digitonin & $0.1 \mathrm{M}$ & $0.5 \mathrm{M}$ \\
EDTA & & \\
Ethanol & $0.1 \mathrm{M}$ & $0.1 \mathrm{M}$ \\
Glycine & & \\
Hanks' balanced salt & $0.1 \mathrm{M}$ & $1.0 \mathrm{M}$ \\
Hepes buffer & $1.0 \mathrm{M}$ & $0.5 \mathrm{M}$ \\
Mercaptoethanol & $5.0 \mathrm{M}$ & $5.0 \mathrm{M}$ \\
NaCl & $1.0 \%$ & $5.0 \%$ \\
PEG 8000 & $0.1 \%$ & $1.0 \%$ \\
SDS & $0.1 \%$ & $0.25 \%$ \\
Triton $X-100$ & $2.0 \mathrm{M}$ & $2.0 \mathrm{M}$ \\
Tris buffer & $2.0 \mathrm{M}$ & $2.0 \mathrm{M}$ \\
Urea & & \\
\hline
\end{tabular}

Note. NC, not compatible; C, compatible.

"Data taken from Ref. (12) (except digitonin which was tested by us). Listed reagents show little or no interference with respect to bovine albumin and globulin.

${ }^{b}$ Interference at the indicated maximal concentrations was tested with respect to BSA in the assay (see Materials and Methods).

(PEG), and glycine were also examined. Urea at $4 \mathrm{M}$ and mercaptoethanol at $2 \mathrm{M}$ resulted in lower signals on densitometric scans (by 9 and $11 \%$, respectively). The presence of $20 \%$ PEG and $1 \mathrm{M}$ glycine caused spreading of the colored spots with approximately $10 \%$ decrease in color intensity. The same reagents have also been examined in the Bradford's method by utilizing the Bio-Rad protein assay procedure (12) and limits of interference were listed in Table 1 for comparison. In most cases, the tolerance of the present dot-blot assay for interfering substances was found to be as good as or better than the Bradford assay.

\section{Assay of Different Proteins}

Diluted stock solutions $(0.004-2 \mathrm{mg} / \mathrm{ml})$ of six different proteins were assayed as triplicates of $1-\mu l$ spots on separate NC sheets. Densitometric areas obtained for each protein set in the linear regime are shown in Fig. 6. Detection limits for test proteins were determined as $4 \mathrm{ng}$ for BSA, hSA, and rIgG and $8 \mathrm{ng}$ for LYS and bINS. The dot-blot assay was relatively less sensitive for OVA and TRI such that less than $16 \mathrm{ng}$ of those could not be detected in the assay. Same protein concentrations were also measured using a microplate version of the Bradford assay (Bio-Rad)for comparison. Measured concentrations for gravimetrically prepared

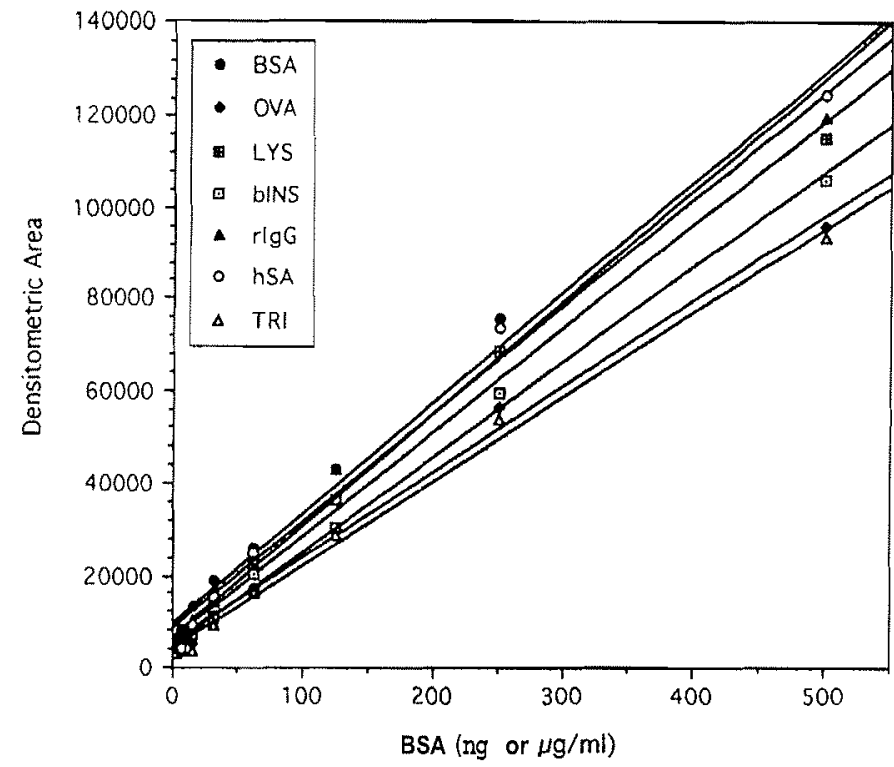

FIG. 6. Densitometric scan of six different proteins on NC in the linear concentration range of $4 \mu \mathrm{g} / \mathrm{ml}$ to $500 \mu \mathrm{g} / \mathrm{ml}$ in PBS, $\mathrm{pH} 7.2$ (see Materials and Methods for details). Regression equations: (BSA) $y=9.4 e^{+3}+239.9 \sim($ OVA $) y=5.4 e^{+3}+186.1 x$; (LYS) $y=5.9 e^{+3}+$ $226.2 \sim$ (bINS) $y=4.5 e^{+3}+206.9 x ;(\mathrm{rIgG}) y=8.5 e^{+3}+233.3 \sim(\mathrm{hSA})$ $y=6.8 e^{+3}+242.6 \sim$ (TRI) $y=4.0 e^{+3}+183.5 x$. Correlation coefficients squared $\left(\mathrm{R}^{2}\right)$ for all are 0.989 or higher.

$1 \mathrm{mg} / \mathrm{ml}$ protein from both assays are compared in Table 2. As shown in Table 2, our present solid-phase detection assay was not significantly affected by protein-to-protein variations in most cases. For example, approximately $97 \%$ of $\operatorname{IgG}$ could precisely be measured in our assay using BSA as the protein reference. The same was only about $60 \%$ of the weighed total protein in the Bradford assay. To overcome this limitation in the Bradford method, Bio-Rad provides a separate bovine y-globulin standard to be used for IgG quantifica-

TABLE 2

Comparison of Bio-Rad and Dot-Blot Assays for Six Proteins

\begin{tabular}{lcc}
\hline & Bio-Rad assay (\%) & Dot-Blot assay (\%) \\
\hline Bovine scrum albumin & 100 & 100 \\
IgG (rabbit, polyclonal) & 56 & 97 \\
Insulin (bovine pancreas) & 48 & 86 \\
Ovalbumin (chicken egg) & 28 & 78 \\
Human serum albumin & 98 & 101 \\
Lysozyme & 98 & 94 \\
Trypsin inhibitor (soy) & 55 & 76 \\
\hline
\end{tabular}

Note, Assays wcre performed on appropriate dilutions of gravimetrically prepared $l \mathrm{mg} / \mathrm{ml}$ stock solution of each protein. Gravimetrically prepared bovine serum albumin was used as the protein standard in both assays. Performance of each test for measuring other six proteins was estimated with respect to BSA from the ratios of slopes (Fig. 6) using the formula: \% accuracy $=[(\mathrm{S}$ test $) /(\mathrm{S} \mathrm{BSA})] \times 100$. 
tion. A similar limitation was also true for insulin. When assayed with the Bio-Rad's detection method using BSA as the assay standard, only $50 \%$ of insulin could be detected. Bio-Rad recommends the use of separate protein standards, instead of BSA, for certain proteins in the assay, whereas we were able to measure insulin with much higher accuracy $(80 \%)$ by utilizing our dot-blot procedure and BSA as the reference protein. Our data suggest that a variety of proteins can be measured with $75-100 \%$ accuracy by using one protein standard (BSA) (Table 2). On the other hand, Bio-Rad's detection system was found limited in the $30-100 \%$ accuracy range for the same test proteins.

\section{DISCUSSION}

We propose the solid-phase protein assay described in this article as an alternative protein detection system to the commonly used Bradford assay in protein laboratories. In the Bradford assay, the presence of most detergents and basic buffer conditions can be incompatible and separate protein standards may be required for different conditions. Our protein assay technique shows tolerance to extreme $\mathrm{pH}$ and buffer conditions and is compatible for high detergent concentrations. Although using BSA prepared in $\mathrm{pH} 7$ buffer condition as the assay standard generally works for most detergent conditions, it is advisable that the protein standard should also be prepared in the appropriate detergent when higher accuracy in estimation is required.

Protein-to-protein variations were found to be significantly less than the variations obtained for the Bradford assay. Using our assay technique, proteins can be measured with equal or greater accuracy in comparison to the Bradford technique. We demonstrated that using BSA as the protein standard works well with most proteins in the dot-blot assay. However, when absolute accuracy is needed, the standard curve must be prepared using a purified sample of the target protein in the same buffer system of the test sample. Once the standard working conditions and the preparatory steps of the assay are established, measurements or estimations can be carried out in a very short time. Our solid-phase protein assay technique can be used in routine protein detections once the following steps are prepared beforehand (to provide speed in assaying with no significant loss in sensitivity): (i) $\mathrm{NC}$ membranes can be precut in various sizes and prestained with Ponceau $\mathrm{S}$ and dried at room temperature as explained under Materials and Methods. Prestained membranes can be stored covered at room temperature for at least 6 months. (ii) Multiple strips or sheets of prestained NC membrane can be spotted with the protein standard of known, concentration, such as BSA, dried, and then stored at room temperature for long period of times (at least 6 months). Prespotted membranes can be developed at the same time with the test samples. Thus, preparation of the protein reference during the time of the assay could be eliminated saving time. Various standard strips of $\mathrm{NC}$ can he prepared for multiple process conditions to achieve higher precision in the detections (e.g., BSA dilutions in various detergents or in other potential interfering substances). (iii) In case of a need for a quick estimation of protein concentrations, the intensity and the size of the colored spots can be compa ed with that of pre-prepared protein refe ence, visually, and a concentration range can be determined. In such cases, membrane drying and coating for densitometric quantification will not be necessary. Comparison can be made by visual examination of the color and/or measuring the spot diameter on freshly developed wet membrane strips. (iv) Furthermore, the same BSA reference mem$b$ anes or strips can be used over and over again each time, by simply just rewetting, when new proteins are tested. (v)Strips of BSA-spotted NC membrane(s) can be further processed according to the standard assay procedure and stored coated by lubricating them with mineral oil as described under Materials and Methods. Even when they appear slightly faded over time, lub ication always restores the brightness of the protein spots.

Staining, or saturation, of membranes with Ponceau $S$ and drying prior to sample application prevented spot spreading and thus helped to obtain tighter and quantifiable protein spots following color development. Visual and densitometric comparison of the signals from prestained and untreated membranes suggested that Ponceau $S$ prestaining also helps prefixation of proteins on the membrane surface. Since Ponceau $\mathrm{S}$ prepared in acidic $\mathrm{pH}$ conditions will provide NC with positive charges, negatively charged proteins will probably interact first electrostatically with the positively charged dye groups on the dehydrated paper, and will precipitate. This interaction is followed by glutaraldehyde fixation which essentially crosslinks the polypeptides to the filter, especially those of low molecular weight with low affinities to NC (such as insulin), thereby covalently stabilizing the protein pattern. Approximately $25 \%$ of the proteins on untreated membranes were washed off during subsequent processing. Samples applied on wet membranes (prestained or untreated) channeled rapidly around the application site while membrane was drying and resulted in patches of irregular/faint red spots upon color development.

In the assay, we have tested triplicates of aged $1-\mathrm{p} 1$ spots of BSA standard dilutions on prestained NC strips for a 6-month period. Staining and the coating of the protein spots were performed on the day of testing. 
Densitometric signals of the stained protein spots were compared with those of freshly prepared membranes. We have also tested the same for dried and then coated NC strips containing $1 \mathrm{pl}$ of BSA dilutions. No notable difference was observed and the typical CV obtained was $55 \%$ in either cases. Thus, we concluded that varying concentrations of BSA spots on pre-Ponceau S-stained NC membrane can be prepared at least 6 months in advance and referred as the protein standard for the assay when testing unknown concentrations.

Within the set of spots containing identical volumes of serial protein dilutions (in the $16 \mu \mathrm{g} / \mathrm{ml}$ to $4 \mathrm{mg} / \mathrm{ml}$ range), we observed a linear correlation between the total amount of protein and the diameter of the stained spot. This may be explained by the relationship between the average binding capacity of $\mathrm{NC}$, which is about $15 \mathrm{pg} / \mathrm{cm}^{2}$ (23), protein concentration, and the diffusion rate of the volume applied. Although we have not thoroughly investigated this relationship yet, our preliminary measurements using a millimeter gauge suggest that the present assay also has the potential to be developed in a dot-metric format. However, with the presented dot-blot detection, a high degree of sensitivity and precision can be achieved regardless of the volume applied within the same set of sample or standard spots by employing diffuse-reflectance densitometry. A linearized analysis of reflected light by surfaces composed of defined particulate (the Kubelka-Monk theory) (24) enables total protein quantification using diffuse-reflectance densitometry at zigzag mode (regardless of the shape or size of the stained spot).

In conclusion, the technique presented in this article can be considered as a potential alternative to the commonly used protein assay techniques. Flexibility of preparing BSA-spotted ready-to-use membrane stocks, in advance, facilitates fast determination of unknowns. Standardization of the technique in a dot-metric scale is currently underway.

\section{ACKNOWLEDGMENTS}

We thank Dr. Steve Bell of BA-Tech for critical reading of the manuscript and helpful discussions and the technical staff at the University of Minnesota for densitometric scanning of the membranes.

\section{REFERENCES}

1. Bradford, M. M. (1976)Anal. Biochem. 72, 248-254.

2. Spector, T. (1978) Anal. Biochem. 86, 142-146.

3. Sedmak, J. J., and Grossberg, S. E. (1977) Anal. Biochem. 79, $544-552$.

4. Smith, P. K., Krohn, R. I., Hermanson, G. T., Mallia, A. K., Gartner, F. H., Provenzano, M. D., Fujimato, E. L., Goeke, N. M., Goeke, B. J.,Olson, B. J., and Klenk, D. C. (1985) Anal. Biochenz. 150,76 .

5. Lowry, O. H., Rosebrough, N. J., Farr, A. L., and Randall, R. J. (1951)J. Biol. Chem. 193, 265-272.

6. Freyer, H. J., Davis, G. E., Manthorpe, M., and Varon, S. (1986) Anal. Biochem. 153, 262.

7. Redinbaugh, M. G., and Turley, R. B. (1986) Anal. Biochem. 153 , 267 .

8. Redinbaugh, M. G., and Campbell, W. H. (1985)Anal. Biochem. 147,144 .

9. Said-Fernandez, S., Gonzalez-Garza, M. T., Mata-Cardanas, B. D., and Navarro-Marmolejo, L. (1990) Anal. Biochem. 191, 119-126.

10. Duhamel, R. C., Meezan, E., and Brendel, K. (1981) J. Biochem. Biophys. Methods 5, 67-74.

11. Kessler, R. J., and Fanestil, D. D. (1986) Anal. Bioclzem. 159, 138 .

12. Bio-Rad Protein Assay, Bio-Rad Laboratories, Technical Bulletin 1069.

13. Stoscheck, C. M. (1990) in Methods in Enzymology: Guide to Protein Purification (Deutscher, M. P., Ed.), Vol. 182, pp. 50-68. Academic Press, San Diego.

14. Li, K. W., Geraerts, W. P. M., van Elk, R, and Joosse, J. (1989) Anal. Biochem. 182, 44-47.

15. Nakamura, K., Tanaka, T., Kuwahara, A., and Takeo, K. (1985) Anal. Biochem. 148, 311-319.

16. Li, K. W., Geraerts, W. P. M., van Elk, R., and Joosse, J. (1988) Anal. Biochem. 174, 97-100.

17. Thornton, D. J., Holmes, D. F., Sheehan, J. K., and Carlstedt, I. (1989) Anal. Biochem. 182, 160-164.

18. Ball, E. H. (1986) Anal. Biochem. 155, 23-27.

19. Parekh, B. S., Mehta, H. B., West, M. D., and Montelaro, R. C. (1985) Anal. Biochem. 148, 87-92.

20. Goldring, J. P. D., and Ravaioli, L. (1996) Anal. Biochem. 242, 197-201.

21. Sheffield, J, B., Graff, D., and Li, H. P. (1987) Anal. Biochem. 166, $49-54$

22. Hunter, J, B., and Hunter, S. M. (1987) Anal. Biochem. 164. $430-433$.

23. Towbin, H., Staehelín, T., and Gordon, J. (1979) Proc. Natl. Acad. Sci. USA 76, 4350-4354.

24. Wendlandt, $W . W$, and Hecht, H. G. (1966) Reflectance Spectroscopy, p.72, Interscience, New York. 